\title{
Implementation of the SERVQUAL Method in Service Quality to Increase Student Satisfaction and Loyalty in Tutoring
}

\author{
Indriana Damaianti ${ }^{1}$, Wiara Sanchia Grafita Ryana Devi ${ }^{2}$, Fitri Dewi Afiany ${ }^{3}$, \\ Fenny Noor Salam ${ }^{4}$, Rifni Nurrahmi ${ }^{5}$ \\ 1,2,3,4,5 Universitas Insan Cendekia Mandiri, Bandung \\ Email: indrianadamaianti05@gmail.com
}

\begin{abstract}
The rapid development in the industrial world causes the importance of a company to provide good service to its customers so that customers will feel satisfied and become loyal to the company. This also applies to companies engaged in tutoring services. Improving service quality can be implemented by implementing the SERVQUAL method to increase satisfaction and loyalty for tutoring students. This research will use qualitative methods with data from previous studies. The research concludes how the implementation of the SERVQUAL method in the service delivery process produces satisfaction for customers or students. This customer satisfaction will then continue to be maintained, leading to loyalty, and customers will not go to other competitors.
\end{abstract}

Keywords: Satisfaction, Loyalty, SERVQUAL Method, Customers.

\section{A. INTRODUCTION}

The emergence of competition in the industrial world is growing rapidly, followed by the development of information technology which has entered various fields of life. Every company, especially those engaged in services, is required to provide good service so that their customers can feel satisfied (Pettit et al., 2019). This is because the key to the company's success is limited to its products and services and how it can provide good service to its customers. This will then make customers feel satisfied with the services and products they have received (Solimun \& Fernandes, 2018).

This problem also applies to companies engaged in tutoring services. Of course, every tutoring service company will provide their best quality so that their students feel satisfied (Draper \& Newton, 2017). But of course, it isn't easy to continuously provide maximum quality and get the results desired by the company and the students. Various errors can occur during the service delivery process, such as the lack of efficiency of the existing system so that the desired results are not optimal, so this has led to criticism of tutoring companies (Mishra et al., 2020).

To solve this problem, tutoring companies need a system that can make it easier to improve the quality of services provided. One method that can be used to achieve this is implementing the service quality (SERVQUAL) method. The use of this method can track the expectations desired by the company with the reality on the ground (Tahanisaz, 2020). Through the discussion above, the researcher then intends to research how to implement the SERVQUAL method in service quality to increase the satisfaction and loyalty of tutoring students.

\section{B. LITERATURE REVIEW}

1. Marketing Concept

The marketing concept is a management philosophy in marketing that is oriented to the needs and desires of consumers, supported by integrated marketing activities aimed at 
providing satisfaction (Hidayanti et al., 2018). So, in this concept, customer satisfaction is the company's main goal because only by satisfying the needs and desires of consumers will repeat purchases which are a condition of the continuity of a company (Sanjaya et al., 2020).

\section{The Nature and Quality of Service}

According to Kotler, service is any activity or benefit offered by one party to another that is essentially intangible and does not result in ownership.

From this description, examples of purchasing services include; rent hotel rooms, bank deposits, repairs in workshops, tutoring, courses, and tutoring services (Faturohman, 2021). From the example above, the nature of the service is reflected, namely;
a. Intangibility
b. Inseparability
c. Variability
d. Perishability

\section{Customer satisfaction}

Customer satisfaction is closely related to quality; quality directly impacts product performance and thus customer satisfaction. To find out the customer satisfaction problem regarding the quality of service received by consumers, one must first understand the meaning of satisfaction itself (Kant \& Jaiswal, 2017). Satisfaction is a person's emotional response to something. Consumer satisfaction is a basic need that can be described as pleasant. When satisfaction arises, and the urge is not channeled, it will appear dissatisfied (Armbrecht \& Andersson, 2020).

Along with advances in technological developments, consumer demands for quality services are increasing. In the past, consumers bought a product or service only based on their needs. Nowadays, consumers are more demanding and pay more attention to quality issues (Libai et al., 2020).

Customers are people who have bought and used a product or service at a company (Rahmayanti \& Saudi, 2021). Customer satisfaction is a process of repurchasing with the same product where the chosen alternative is at least equal to or exceeds customer expectations, while dissatisfaction arises when the outcome does not meet expectations (Narotama, 2019). Engel and Pawitra say that this understanding can be applied in assessing satisfaction or dissatisfaction with a particular company because both are closely related to the concept of customer satisfaction (Pakurar et al., 2019).

Companies use many ways to satisfy their customers because when customers are satisfied, they will be loyal, which is reflected in them:

a. Make repeat purchases (repeat buying)

b. Say good things about the company to others (positive referrals)

c. Lack of attention to competing brands or product advertisements

d. Buying other products from the same company (additional business)

e. Willing to buy at a higher price (price-insensitive) (Raza et al., 2020)

\section{Customer Satisfaction in the Service Business}

In a service business that focuses on service in the production and consumption processes, it won't be easy to measure how far the level of customer satisfaction is without involving customer participation in the field to provide opinions and attitudes towards the quality of service received (Cheng et al., 2019).

Zeithaml identified ten general dimensions or determinants of service quality, which determine the level of satisfaction. Based on these dimensions, a formula called SERVQUAL Analysis is made, with a scheme like the one below where out of 10 dimensions are variables 
that become measurements, both in terms of expectations and perceptions of the reality that has occurred (Kayapinar \& Erginel, 2019).

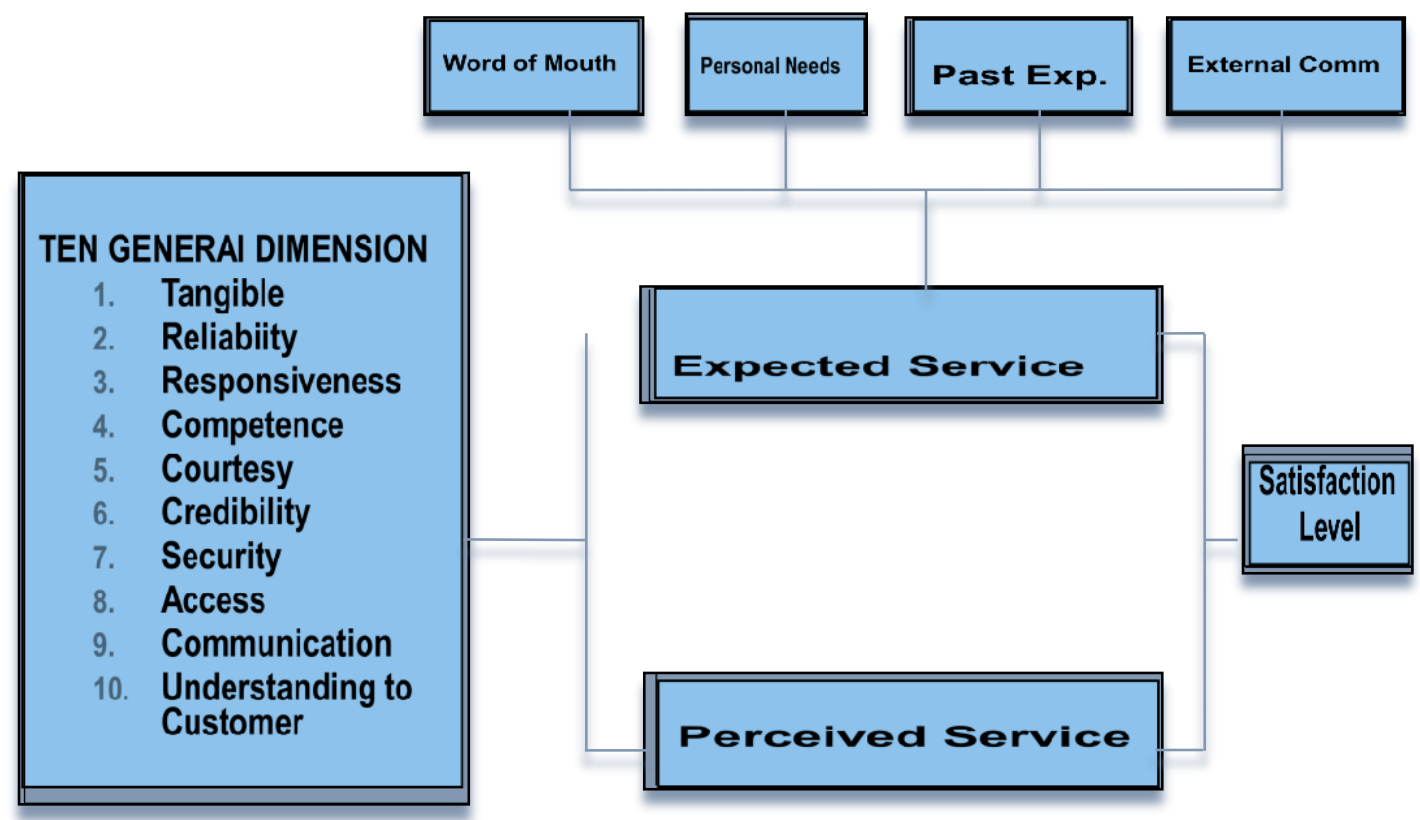

Figure 1. SERVQUAL Concept

The concept above summarizes the ten dimensions of quality into five dimensions in the SERVQUAL Analysis. The five dimensions are as follows:

a. Reliability

The ability of employees to provide services as promised quickly, reliably, accurately, and consistently (Nguyen et al., 2018).

b. Responsiveness

The willingness of employees and managers to help customers and provide services quickly and meaningfully and willingness to hear and resolve customer complaints (Agnihotri et al., 2019).

c. Assurance

The willingness of employees to create confidence and trust in promises that have been made to customers, for example, promises in promotions (Tabrani et al., 2018).

d. Empathy

The willingness of employees and managers to care more about giving personal attention to customers; for example, employees or managers must place themselves as customers (Meng \& Choi, 2018).

e. Tangible

In the form of the appearance of physical facilities, equipment, and various communication materials such as buildings and cleanliness and neat spatial arrangement (Qi et al., 2021).

From the description above, it can be concluded that customer satisfaction is a function of expectations and perceptions of the services provided.

\section{Customer Loyalty}

Customer loyalty is a behavioral impulse to make repeated purchases. Efforts to build customer loyalty to a product/service produced by the company take a long time through repeated purchases. Customers are different from consumers, and a person can be a customer if that person starts to get used to buying products or services offered by business entities 
(Pekovic \& Rolland, 2020).

This habit can be built through repeated purchases within a certain period. If they do not make repeat purchases within a certain time, the person cannot be said to be a customer but a buyer or consumer (Sheth, 2020).

In addition to repeated purchases, customer loyalty is also indicated by the willingness of customers to pay higher prices, not being tempted to try competing company products, willing to try new products, and being willing to recommend people they know to buy the company's products (Contini et al., 2020). From the description above, it can be concluded that customer loyalty is a function of customer satisfaction.

\section{METHOD}

This research was carried out using a qualitative approach. The data is obtained through various previous research results that are still related to the implementation of SERVQUAL in various service fields. Researchers will then analyze the data that has been successfully collected to find the desired results regarding how the implementation of the SERVQUAL method in providing an increase in customer satisfaction and loyalty, especially students.

\section{RESULT AND DISCUSSION}

\section{SERVQUAL's Five Elements and Action Strategy}

a. Tangible

The physical appearance of various facilities and products of a company, such as how the cleanliness and arrangement of the building are located. This also includes the appearance of the employees or staff who teach there.

The implementations that can be done are:

1) Provide an attractive and professional appearance to students who participate in tutoring.

2) Prepare equipment that can be used properly and work properly. Then ensure that the cleanliness and tidiness of a room and various other facilities can be maintained.

3) Professionalism supported by good and supportive body language

b. Reliability

The ability to provide products or services following what has been previously promised quickly, reliably, accurately, and consistently.

The implementations that can be done are:

1) Identify the needs needed by customers or students correctly according to their needs.

2) Only provide products or services that have been previously promised.

3) Follow up on products and services that have been provided so that the results received by customers or students are following what was promised.

c. Assurance

It is the willingness of the company to be able to give confidence and trust to customers or students on the promises that have been given.

The implementations that can be done are:

1) Shows the character and actions of a company that can make customers or students trust the tutoring company.

2) Giving confidence to customers or students that the company can fulfill their needs

d. Responsive

It is the ability to help customers or students provide services that are fast and 
responsive.

The implementations that can be done are:

1) Show a dashing attitude and always seem ready to help

2) Give a positive attitude or a "can-do-attitude."

3) Take immediate action when customers or students have needs that must be met

e. Empathy

Give more personal attention to customers or students when providing products or services needed by them.

The implementations that can be done are:

1) Provide services that are not expected by customers or students

2) Providing services that are not owned by other companies with the same products and services, thus causing the services provided to have unique characteristics

\section{Becoming a High-Level Service Provider}

To provide a high level of service, a company needs to make employees understand several things. Knowledge of these things can then cause companies to know how good service can be provided so that this will then increase satisfaction for customers or students. The things that need to be considered include:

a. Understanding of the company or organization

Understanding the company begins with understanding the purpose of the company's formation. By knowing the goals to be achieved, employees can know their direction. Next is knowing how the culture of the company is being occupied. Knowing this culture will help employees to adapt so they can work optimally. Then employees also need to know how to interact with their customers. Finally, employees also need to know how the company can provide support to its employees regarding the products and services provided to their customers.

b. Understanding of service

Understanding the services provided needs to begin with knowing the characteristics of the services provided. When you know these characteristics, the basics of the services provided will be known. The next step is knowing the development of the product or service being sold. After knowing how the basic services are provided, knowledge of the development of these products and services is also important. Next is knowing how to deliver or deliver the products and services provided. This is because the delivery of services can affect how customers perceive, so this knowledge is quite important. The last thing to know is the value of the services provided. A low service value will certainly not be liked by customers, while service with a high value will be considered quality. The value of the services provided will directly influence customer satisfaction.

c. Understanding of customers

Understanding the customer will start with understanding the needs of the customer. By knowing customer needs, the services provided will be accurate and satisfying. Next is knowing where the customer pays attention. By knowing the attention given, the service can be improved in that section so that customers feel more personalized and satisfied. This is then ended by knowing the personality of the customer. Knowing this personality will facilitate interactions because it can avoid things that customers hate, and at the same time, highlight things that customers like in providing services. These things will increase customer satisfaction in receiving the products and services provided. 


\section{Locking Customer Loyalty}

Locking loyalty is an operating model that can help companies lock customers, so they don't move to competitors and remain satisfied and loyal to their products. In this model, there is a movement in the level of the customer relationship from the time of introduction (awareness), interest (attraction), and buying (transaction). This transaction process creates a process of satisfaction, which continues at the loyalty stage, which consists of the relationship, partnership, and ownership stages. The explanation of this concept in stages can be seen as follows:

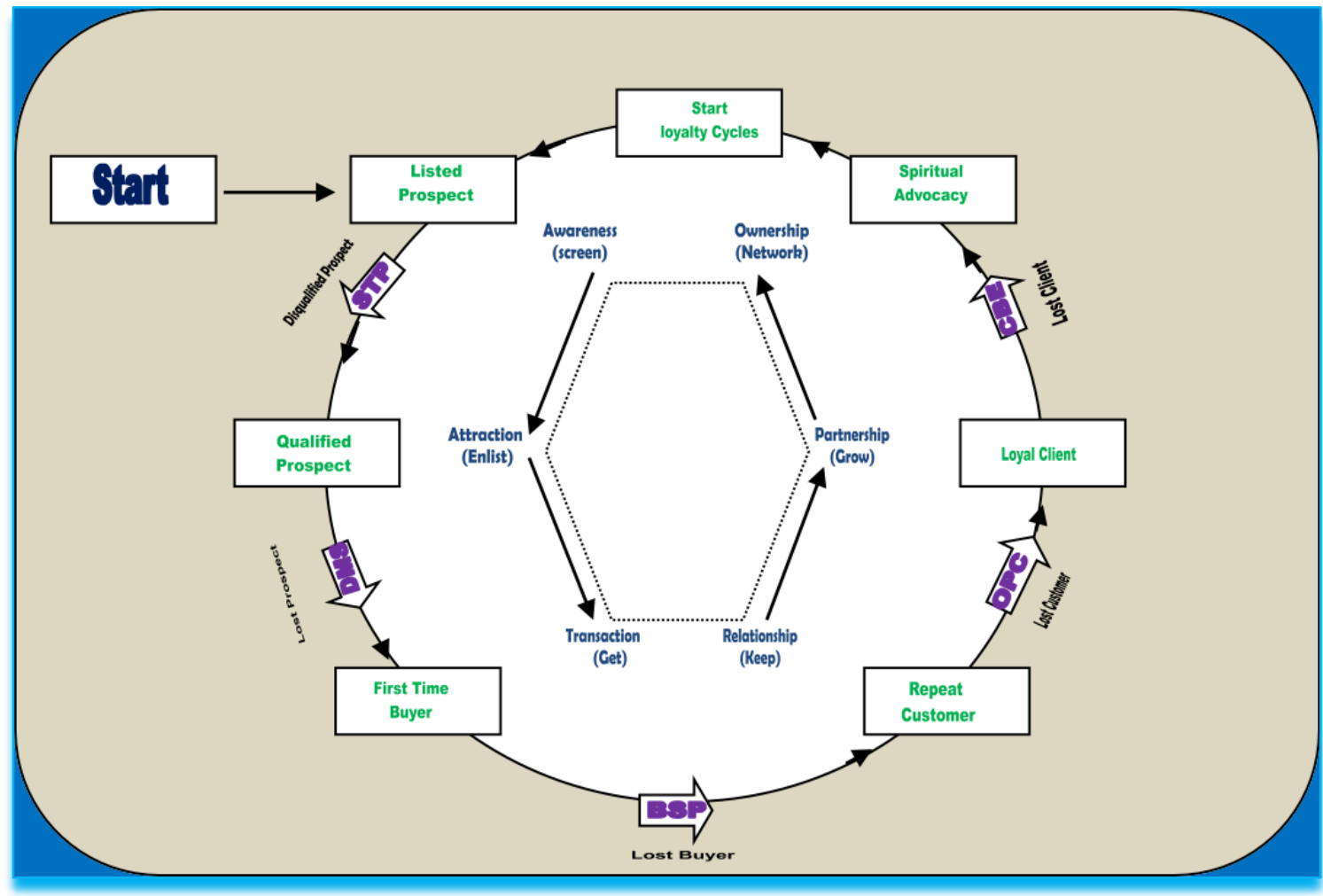

Figure 2. Locking Loyalty Model

Description:

STP: Segmentation, Targeting, Positioning

DMS: Differentiation, Marketing Mix, Selling

BSP: Brand, Service, Process

OPC: Operational Excellence, Product Leadership, Customer Intimacy

CBE: Community, Buzzy, Emotionalization

a. The first element in this model is the stage of customer position in the concept of locking loyalty which starts from suspect, prospect, first-time buyer, repeat customer, loyal client to spiritual advocacy.

b. The second element is the movement of the customer relationship level since the introduction (awareness), interested (attraction), buying (transaction). A deeper relationship (loyalty) is created from this transaction, namely relationship, partnership, and ownership.

c. To capture the most potential prospects from a pool of suspects, companies must properly perform segmentation, targeting, and positioning (STP).

d. To encourage purchases, companies must differentiate products (differentiation), design the right marketing mix, and take an aligned sales approach, abbreviated as DMS. 
e. After a purchase (transaction), the company will maintain the relationship as long as possible by turning the customer into a repeat customer by building a brand, service, and process (BSP). Brand increases value, service increases confidence, and reduces other costs, enabling customers to obtain quality products, low costs, and fast service delivery.

f. To get loyal clients, the company must increase the benefits. Companies can improve the consistency of benefits by providing efficient service processes (operational excellence), always developing products to be the best (product leadership), and always getting closer to customers by increasingly understanding their needs and desires (customer intimacy), which is abbreviated as OPC.

g. To get to the highest level of loyalty, namely ownership, the company must further increase its benefits by sharing experiences, forming communities (community), creating buzzwords (buzzing).

\section{E. CONCLUSION}

The discussion above shows that the SERVQUAL method can be used to increase satisfaction and create loyalty for tutoring students. This can be done by increasing student satisfaction first through the SERVQUAL method. The satisfaction that has been obtained will then be locked through the Locking Loyalty method. That way, student loyalty can be guaranteed because previous students have been satisfied with the services they have received.

\section{REFERENCES}

Agnihotri, R., Yang, Z., \& Briggs, E. (2019). Salesperson time perspectives and customer willingness to pay more: roles of intraorganizational employee navigation, customer satisfaction, and firm innovation climate. Journal of Personal Selling \& Sales Management, 39(2), 138-158.

Armbrecht, J., \& Andersson, T. D. (2020). The event experience, hedonic and eudaimonic satisfaction and subjective well-being among sport event participants. Journal of Policy Research in Tourism, Leisure and Events, 12(3), 457-477.

Cheng, B. L., Gan, C. C., Imrie, B. C., \& Mansori, S. (2019). Service recovery, customer satisfaction and customer loyalty: Evidence from Malaysia's hotel industry. International Journal of Quality and Service Sciences.

Contini, M., Annunziata, E., Rizzi, F., \& Frey, M. (2020). Exploring the influence of Corporate Social Responsibility (CSR) domains on consumers' loyalty: an experiment in BRICS countries. Journal of Cleaner Production, 247, 119158.

Draper, M. J., \& Newton, P. M. (2017). A legal approach to tackling contract cheating?. International Journal for Educational Integrity, 13(1), 1-16.

Hidayanti, I., Herman, L. E., \& Farida, N. (2018). Engaging customers through social media to improve industrial product development: the role of customer co-creation value. Journal of Relationship Marketing, 17(1), 17-28.

Kant, R., \& Jaiswal, D. (2017). The impact of perceived service quality dimensions on customer satisfaction: An empirical study on public sector banks in India. International Journal of Bank Marketing.

Kayapınar, S., \& Erginel, N. (2019). Designing the airport service with fuzzy QFD based on SERVQUAL integrated with a fuzzy multi-objective decision model. Total Quality Management \& Business Excellence, 30(13-14), 1429-1448.

Libai, B., Bart, Y., Gensler, S., Hofacker, C. F., Kaplan, A., Kötterheinrich, K., \& Kroll, E. B. (2020). Brave new world? On AI and the management of customer 
relationships. Journal of Interactive Marketing, 51, 44-56.

Meng, B., \& Choi, K. (2018). An investigation on customer revisit intention to theme restaurants: The role of servicescape and authentic perception. International Journal of Contemporary Hospitality Management.

Mishra, L., Gupta, T., \& Shree, A. (2020). Online teaching-learning in higher education during lockdown period of COVID-19 pandemic. International Journal of Educational Research Open, 1, 100012.

Nandang Faturohman, S. (2021). Quality of Academic Service During the Covid-19 Pandemic at STKIP Setia Budhi Rangkasbitung. Review of International Geographical Education Online, 11(10), 1329-1334.

Narotama, A. (2019). The effect of service quality on customer loyalty with brand images and customer satisfaction as mediation. Jurnal manajemen dan kewirausahaan, 7(1), 8693.

Nguyen, Q., Nisar, T. M., Knox, D., \& Prabhakar, G. P. (2018). Understanding customer satisfaction in the UK quick service restaurant industry: The influence of the tangible attributes of perceived service quality. British Food Journal.

Pakurár, M., Haddad, H., Nagy, J., Popp, J., \& Oláh, J. (2019). The service quality dimensions that affect customer satisfaction in the Jordanian banking sector. Sustainability, 11(4), 1113.

Pekovic, S., \& Rolland, S. (2020). Recipes for achieving customer loyalty: A qualitative comparative analysis of the dimensions of customer experience. Journal of Retailing and Consumer Services, 56, 102171.

Pettit, T. J., Croxton, K. L., \& Fiksel, J. (2019). The evolution of resilience in supply chain management: a retrospective on ensuring supply chain resilience. Journal of Business Logistics, 40(1), 56-65.

Qi, Q., Tao, F., Hu, T., Anwer, N., Liu, A., Wei, Y., ... \& Nee, A. Y. C. (2021). Enabling technologies and tools for digital twin. Journal of Manufacturing Systems, 58, 3-21.

Rahmayanti, R., \& Saudi, M. H. (2021). E Word of Mouth and Structural Geography Predicting the Consumer Behavior in Traditional Market During Covid-19 Pandemic. Review of International Geographical Education Online, 11(3), 253-264.

Raza, A., Saeed, A., Iqbal, M. K., Saeed, U., Sadiq, I., \& Faraz, N. A. (2020). Linking corporate social responsibility to customer loyalty through co-creation and customer company identification: Exploring sequential mediation mechanism. Sustainability, 12(6), 2525.

Sanjaya, P. K. A., Wimba, I. G. A., \& Premayani, N. W. (2020). Determinants Influencing Customer Loyalty to An Indonesian Online Shop Shopee: A Case Study in Denpasar City, Bali. Solid State Technology, 63(5), 4713-4722.

Sheth, J. (2020). Impact of Covid-19 on consumer behavior: Will the old habits return or die?. Journal of business research, 117, 280-283.

Solimun, S., \& Fernandes, A. A. R. (2018). The mediation effect of customer satisfaction in the relationship between service quality, service orientation, and marketing mix strategy to customer loyalty. Journal of Management Development.

Tabrani, M., Amin, M., \& Nizam, A. (2018). Trust, commitment, customer intimacy and customer loyalty in Islamic banking relationships. International Journal of Bank Marketing.

Tahanisaz, S. (2020). Evaluation of passenger satisfaction with service quality: A consecutive method applied to the airline industry. Journal of Air Transport Management, 83, 101764. 